OPEN ACCESS

Edited by:

Simon Blank,

Helmholtz Zentrum

München, Germany

Reviewed by:

Girolamo Pelaia,

University of Catanzaro, Italy

Bernahrd Ryffel,

Centre National de la Recherche

Scientifique (CNRS), France

*Correspondence:

Michał Panek

michalmp@poczta.onet.pl

Specialty section:

This article was submitted to

Immunological Tolerance and

Regulation,

a section of the journal

Frontiers in Immunology

Received: 09 April 2020

Accepted: 11 May 2020

Published: 18 June 2020

Citation:

Kardas G, Kuna P and Panek M (2020) Biological Therapies of Severe Asthma and Their Possible Effects on

Airway Remodeling.

Front. Immunol. 11:1134

doi: 10.3389/fimmu.2020.01134

\section{Biological Therapies of Severe Asthma and Their Possible Effects on Airway Remodeling}

\author{
Grzegorz Kardas, Piotr Kuna and Michał Panek* \\ Clinic of Internal Medicine, Asthma and Allergy, Medical University of Lodz, Łódz, Poland
}

Asthma is a chronic and heterogenic respiratory tract disorder with a high global prevalence. The underlying chronic inflammatory process and airway remodeling (AR) contribute to the symptomatology of the disease. The most severely ill asthma patients may now be treated using a variety of monoclonal antibodies aiming key inflammatory cytokines involved in asthma pathogenesis. Although clinical data shows much beneficial effects of biological therapies in terms of reduction of exacerbation rates, improvement of lung functions, asthma control and patients' quality of life, little is known on the effects of these monoclonal antibodies on AR-a key clinical trait of long-term asthma management. In this review, the authors summarize the data on the proven effects of monoclonal antibodies in asthma on AR. To date, in terms of reversing AR, the mostly studied was omalizumab. However, some studies also addressed this clinical issue in context of other severe asthma biological therapies (mepolizumab, benralizumab, tralokinumab). Still, data on effects of particular biological therapies on AR in severe asthma are incomplete and require further studies. According to the American Thoracic Society research recommendations, future research shall focus on AR in asthma and improve drugs targeting AR, including the available and future monoclonal antibodies.

Keywords: asthma, airway remodeling, airway remodeling in asthma, biological therapy, omalizumab, mepolizumab/reslizumab, benralizumab

\section{INTRODUCTION}

Asthma is a chronic, heterogeneous and inflammatory respiratory condition characterized by shortness of breath, cough, wheezing, and chest tightness. It belongs to the group of obstructive diseases for which the variable airflow limitation is characteristic (1). Various asthma phenotypes differ in causes and mechanism of symptom formation, and thus in severity and frequency of symptoms and exacerbations (2). Currently, asthma affects $1-18 \%$ of the population in various countries $(1,3,4)$. It occurs in all age groups, with new diagnoses mostly made in children aged 0-9 [early-onset asthma, usually atopic (5)] and in adults aged 40-49 [late-onset asthma, often with eosinophilic phenotype (6)]. Noteworthy is that not only asthma, but also other allergic diseases'-urticaria, allergic rhinitis or food allergies-prevalence increase worldwide (4, $7,8)$. The causes of this epidemiological phenomenon mainly include: environmental changes associated with the modification of the surrounding microbiome affecting microbiological and immunological changes in the human respiratory tract from the earliest years of life (the so-called "hygiene theory"), past respiratory infections, exposure to allergens, air pollution, and other pollutants $(9,10)$. 
Currently, "asthma" is considered an umbrella term, which encompasses several, both clinically and pathophysiologicaly different variants of the disease. The two main divisions concern the type of inflammation: $\mathrm{T}_{\mathrm{h}} 2$-predominant and non- $\mathrm{T}_{\mathrm{h}} 2$. Further, phenotypes are distinguished as either eosinophilic asthma or non-eosinophilic (11). In particular, among $\mathrm{T}_{\mathrm{h}} 2$ predominant phenotypes, the most prevalent endotype is the allergic asthma. It develops on basis of atopy, in particular in response to inhaled allergens such as house dust mites, grass pollen, trees, and pets (6). Apart from classical childhood-onset allergic asthma, late-onset eosinophilic asthma is now one of the best-defined phenotypes (12). Several other endotypes of asthma include obesity-associated asthma, neutrophilic asthma, very-late onset asthma and other.

In the pathogenesis of the disease, mediators of the $T_{h} 2$ dependent reaction play a key role, including: IgE, IL-3, IL4, IL-5, IL-13, IL-33, TSLP, and other (13). In non-allergic asthma, although the cellular pathomechanism is different, most of the mediators remain the same, with main variations including IL-17 and $\mathrm{PGD}_{2}$. The underlying immunopathological mechanisms of asthma lead to chronic airway inflammation resulting in number of consequences for the bronchi. The airways become hypersensitive and constrict when subject to stressful stimuli. Another result of this ongoing inflammation is airway remodeling (AR), a process of structural changes of bronchi walls. The chronic airway inflammation thus leads to reduced airway airflow and clinical symptoms-wheezing, shortness of breath cough, chest tightness. Unfortunately, those symptoms are few and non-specific, thus the differential diagnosis of asthma is often difficult. Additionally, asthma is often associated with comorbidities, including: other allergic conditions (rhinosinositus, nasal polyps, atopic dermatitis), obesity, diabetes, gastroesophageal reflux, depressive and anxiety disorders, and other (14).

In clinical practice, we distinguish 3 levels of asthma severity (mild, moderate and severe) and 5 Global Initiative for Asthma (GINA) treatment steps (1). Mild asthma comprises of GINA steps 1 . and 2. Moderate asthma, characterized by more severe symptoms and more frequent exacerbations is GINA step 3. Severe asthma are GINA steps 4 . and 5. The most severely ill patients, i.e., those who do not achieve asthma control despite using high doses of inhaled steroids, are qualified for step 5. biological treatment with monoclonal antibodies against key asthma mediators. The overall clinical goal in asthma is disease control, i.e., a therapy that provides optimal symptom reduction. Drugs and their doses are modified depending on the symptoms, severity of the disease and exacerbation frequency. Treatment may be intensified in absence of control or reduced if long-term, optimal disease control is achieved.

\section{AIRWAY REMODELING IN ASTHMA}

In the pathogenesis of asthma symptoms, bronchospasm under the influence of external stimuli plays a key role (15). Simultaneously, the inflammation that occurs in the bronchi is responsible for the onset of symptoms. Currently, another
TABLE 1 | Key molecular factors contributing to airway remodeling (in particular - the factors that are aimed by currently available or investigated biological therapies of asthma).

\begin{tabular}{|c|c|c|}
\hline Factor & Key effect(S) on airway remodeling & References \\
\hline $\lg E$ & $\begin{array}{l}\text { 1. Indirect contribution-IgE stimulates production of } \\
\text { cytokines involved in airway remodeling (IL-4, IL-5, } \\
\text { IL-13, TGF } \beta 1 \text {, and other) during the late phase } \\
\text { 2. Direct contribution-induction of ASM proliferation } \\
\text { in vitro }\end{array}$ & $\begin{array}{l}\text { 1. }(25) \\
\text { 2. }(26)\end{array}$ \\
\hline IL-4 & $\begin{array}{l}\text { 1. Increased synthesis of } \alpha \text {-smooth muscle actin and } \\
\text { collagen III } \\
\text { 2. Induction of TGF- } \beta \text { release by airway epithelial cells }\end{array}$ & $\begin{array}{l}\text { 1. }(27) \\
\text { 2. }(28)\end{array}$ \\
\hline IL-5 & $\begin{array}{l}\text { 1. Promotion of subepithelial and peribronchial fibrosis } \\
\text { by eosinophil recruitment and subsequent production } \\
\text { of TGF } \beta 1\end{array}$ & 1. $(29,30)$ \\
\hline IL-13 & $\begin{array}{l}\text { 1. Induction of TGF- } \beta \text { release by airway epithelial cells } \\
\text { 2. Changes in goblet cell density }\end{array}$ & $\begin{array}{l}\text { 1. }(28,31) \\
\text { 2. }(32)\end{array}$ \\
\hline IL-17 & $\begin{array}{l}\text { 1. Promotion of ASMC migration } \\
\text { 2. Increase of matrix metaloproteinases } \\
\text { 3. Cross-talk with TGF } \beta 1 \text { resulting in EMT } \\
\text { 4. Stimulation of inactive fibrocytes maturation to } \\
\text { fibroblast, which deposit collagen within ECM }\end{array}$ & $\begin{array}{l}\text { 1. (33) } \\
\text { 2. }(34) \\
\text { 3. }(35) \\
\text { 4. }(36)\end{array}$ \\
\hline TSLP & $\begin{array}{l}\text { 1. Promotion of collagen deposition } \\
\text { 2. Goblet cells hyperplasia } \\
\text { 3. Local eosinophil recruitment in airway } \\
\text { 4. Increase in type-I collagen and } \alpha \text {-SMA expression in } \\
\text { human lung fibroblasts }\end{array}$ & $\begin{array}{l}1,2,3 \cdot(37) \\
\text { 4. (38) }\end{array}$ \\
\hline
\end{tabular}

distinguished disease component is AR, i.e., a process of reconstruction of the bronchi wall. Much research is currently focused on AR, the understanding of which will allow to search for new therapeutic possibilities of asthma $(16,17)$.

Chronic respiratory epithelium inflammation leads to changes in microvascularization, thickening of the airway walls and impaired airflow through the bronchi, and consequently to impaired ventilation (18). Thus, AR is a change of composition, content and distribution of cellular and molecular components in the airway wall (19). In asthma, it is associated with many structural changes-epithelial damage, subepithelial fibrosis, angiogenesis, hypertrophy and proliferation of myofibroblasts and myocytes and increased number of smooth muscle fibers in airway smooth muscle cells (ASMC), that increase airway smooth muscle (ASM) mass (20,21). A number of inflammatory molecular factors are involved in these structural changes, either directly or via further induction of inflammatory reaction, namely eosinophilic (22). Starting with the local epitheliumderived factors, the key AR mediators include: PDGF (plateletderived growth factor), TGF $\beta$ (transforming growth factor $\beta$, with particular emphasis on TGF $\beta_{1}$, among its three isoforms), FGF (fibroblast growth factor), EGF (epidermal growth factor), prostaglandin D2 (PGD2), CXCL2, CXCL3, IL-8, eotaxin, TSLP, CCL1, and other, which all promote $\operatorname{ASMC}$ migration $(23,24)$. The cytokines produced by $\mathrm{T}_{\mathrm{h}} 2$ (IL-4, IL-13) and $\mathrm{T}_{\mathrm{h}} 17$ cells (IL-17, IL-21, IL-22, TNF $\alpha$ ) share the same effect. All of the inflammatory factors that are targeted by currently available and investigated biological therapies contribute to AR. The summary of their effects on particular components of AR is available in Table 1. 
Currently, the possible role of epithelial-mesenchymal transition (EMT) in AR is also strongly discussed. EMT is a transformation of epithelial cells into mesenchymal-like cells by loss of their epithelial traits (39). Features of EMT in AR are currently intensively studied and emerging studies confirm that EMT occurs in AR in asthma $(40,41)$. A major mediator of that process is $\mathrm{TGF} \beta_{1}$, which has been proven to induce EMT of airway epithelial cells-this process occurs to a greater extent in cells of asthmatic than of non-asthmatic patients (42). It is thus worth to pay attention to the inflammation mediators which are targeted by biological therapies of severe asthma and their effect on TGF $\beta_{1}$-mediated EMT [eg. IL-4, IL-17 $\left.(35,43)\right]$. In vitro studies also show that neutrophils from severe asthmatics induce EMT in healthy bronchial epithelial cells via TGF $\beta_{1}$ dependencies (44). A need for further research in this area is suggested in the literature $(40,45,46)$.

As a result of AR, patients may experience irreversible airway obstruction which leads to worsening of lung function, airway dilatation and response to bronchodilators. AR thus significantly contributes to the development and long-lasting persistence of asthma symptoms $(16,47-49)$.

\section{SEVERE ASTHMA AND ITS BIOLOGICAL THERAPY}

Severe asthma affects $3.6-10.0 \%$ of patients with asthma (5052 ), which corresponds to around 4 million patients globally. Currently, much research is focused on pathomechanisms of severe asthma and development of its new biological therapies (53). Although it is much less prevalent than mild and moderate asthma, severe asthma contributes to about $60 \%$ of costs associated with this disease, mainly due to drug costs $(54,55)$.

The ground-breaking achievement in severe asthma treatment was the introduction of its first biological treatment-anti-IgE monoclonal antibody omalizumab. The following years brought further biological agents aimed at different factors, including IL5, IL-5R, IL-13, IL-4R, and other. Each of these drugs blocks a certain immunological pathway triggering and controlling the allergic or non-allergic airway inflammation. With the nowavailable monoclonal antibodies in asthma, clinicians may select a drug according to asthma phenotype. Currently, approved by the FDA and available on the market are: omalizumab, mepolizumab, benralizumab, reslizumab, and dupilumab (56).

Omalizumab is a humanized IgG1/ $\kappa$ monoclonal antibody that binds to the IgE immunoglobulin Fc fragment (57). Thus, it inhibits the main mediator of type I reaction pathway. By binding blood-circulating free IgE molecules, it inhibits the activation of mast cells and basophils (58). Launched in 2003, omalizumab has been used in severe allergic asthma and, since 2014, in chronic urticaria. Omalizumab is the very first monoclonal antibody included in the GINA recommendations (in 2004) on step 5. as an addition to standard therapy with high doses of inhaled steroids, $\beta 2$-agonists and other drugs. Clinical and observational studies conducted over several years of using omalizumab have proven that it improves asthma control and relieves its symptoms, reduces exacerbation risk and improves lung function (59-61).
Long-term safety of this drug was demonstrated in adults in terms of oncological safety and pregnancy (62-64) and in children (65).

Mepolizumab-another biological drug for severe asthma treatment-was registered in 2015. This antibody binds IL-5, which prevents it from binding to the IL-5R a subunit on eosinophils. This drug is thus used in patients with eosinophilic asthma as by blocking the IL- 5 signaling, the patient's eosinophil population is reduced, which leads to clinical improvement (66). Clinical and observational studies confirmed that mepolizumab used in the treatment of severe eosinophilic asthma improves asthma control, reduces the number of exacerbations and doses of steroids used and improves lung function $(67,68)$. Importantly, both mepolizumab and omalizumab exhibit a comparable safety profile (69).

Whilst having achieved greatly beneficial clinical effects with biological treatment, as research in severe asthma progressed, further drugs were introduced by FDA, including: benralizumab (which targets IL-5R $\alpha$ subunit), dupilumab (which inhibits IL4 and IL-13 signaling) and reslizumab (anti-IL-5 antibody) (56, $70,71)$. The summary of their biological and clinical effects is available in Table 2.

\section{EFFECTS OF PARTICULAR BIOLOGICAL DRUGS ON AIRWAY REMODELING}

AR in asthma is mainly caused by long-term, uncontrolled airway inflammation (16). With the duration of the disease and its symptoms, structural changes in the bronchi progress, which may lead to a significant and long-term impairment of lung function (49). Considering the above and the immunomodulatory effect of biological therapies, it may be assumed that these drugs may significantly affect AR. However, data on this subject are limited and few studies cover this clinical aspect. A summary of research covering biological therapies' impact on AR is available in Table 2.

\section{Omalizumab}

Roth et al. described the effects of IgE-contained serum from allergic asthma patients on ASM cells. The effects of such incubation were: ASM cells proliferation, deposition of type-I collagen in $48 \mathrm{~h}$ and of fibronectin in $24 \mathrm{~h}$. A $1 \mathrm{~h}$ pre-incubation of ASM cells with omalizumab, prevented these three effects. The addition of allergens did not increase the IgE-dependent effects on cells incubated in omalizumab (73). Another interesting study on omalizumab was published by Huang et al. (72), in which the authors analyzed of omalizumab on allergen- and IL1 $\beta$ stimulated proinflamatory cytokine and nitric oxide production in human bronchial epithelial cells (BECs) and compared them to those of budesonide. In that study omalizumab shared similar effects as budesonide in decrease of TNF- $\alpha$, TGF $\beta$ and IL-4 production (72).

In 2012 Hoshino and Ohtawa compared 16 patients on omalizumab to 14 patients with conventional severe asthma treatment and measured their airway dimensions with high-resolution computed tomography (HRCT). A 16-week 
TABLE 2 | Summary on biologic therapies for the treatment of severe asthma and with their clinical effects and confirmed effects on AR.

\begin{tabular}{|c|c|c|c|c|c|c|c|}
\hline & Drug & Form & Target & Biological effects & Clinical effects & Effects on airway remodeling & $\begin{array}{l}\text { Other fda-approved } \\
\text { indications }\end{array}$ \\
\hline \multirow[t]{5}{*}{$\begin{array}{l}\text { FDA-approved } \\
\text { monoclonal antibodies } \\
\text { for treatment of } \\
\text { moderate-to-severe } \\
\text { asthma }\end{array}$} & Omalizumab & $\begin{array}{l}\text { Humanized } \\
\operatorname{lgG} 1 / \kappa \\
\text { monoclonal } \\
\text { antibody }\end{array}$ & $\lg E$ & $\begin{array}{l}\circ \downarrow \text { circulating total IgE } \\
\circ \text { Down-regulation of FcERI } \\
\text { receptors on basophils, mast } \\
\text { cells, and dendritic cells }\end{array}$ & $\begin{array}{l}\text { - Improvement of lung function (FEV1) } \\
\text { - Improvement of quality of life (AQLQ) } \\
\text { - Improvement of asthma control (ACT) } \\
\text { - } \downarrow \text { oral and inhaled corticosteroid use } \\
\text { - Reduction in exacerbation and } \\
\text { hospitalization frequency (59) }\end{array}$ & $\begin{array}{l}\text { - Reduction of production of TNF- } \alpha, \text { TGF } \beta \\
\text { and IL-4 in bronchial epithelial cells (72) } \\
\text { - Prevention of ASM cell remodeling } \\
\text { in vitro(73) } \\
\text { - Reduction of airway wall thickness in } \\
\text { computed tomography }(74,75)\end{array}$ & - Chronic idiopathic urticaria \\
\hline & Mepolizumab & $\begin{array}{l}\text { Humanized } \\
\text { lgG1/k, } \\
\text { monoclonal } \\
\text { antibody }\end{array}$ & IL-5 & $\begin{array}{l}\text { - Blockage of IL-5/L-5R } \\
\text { binding on eosinophils } \\
\circ \downarrow \text { blood eosinophils } \\
\circ \downarrow \text { sputum eosinophils }\end{array}$ & $\begin{array}{l}\text { - Reduction in exacerbation frequency vs } \\
\text { placebo } \\
\text { - Improvement in AQLQ vs placebo } \\
\text { - No significant effect on FEV1, } \\
\text { PEF, } \mathrm{PC}_{20}(76)\end{array}$ & $\begin{array}{l}\text { - Reduction of airway remodeling markers } \\
\text { (tenascin, lumican, and procollagen III) } \\
\text { and airway eosinophils expressing TGF } \beta 1 \\
\text { in bronchial reticular basement } \\
\text { membrane and reduction of TGF } \beta 1 \text { in } \\
\text { bronchioalveolar lavage after } \\
\text { mepolizumab treatment (77) } \\
\text { - Reduction of AR observed in } \\
\text { computed tomography (78) }\end{array}$ & NA \\
\hline & Benralizumab & $\begin{array}{l}\text { Humanized } \\
\text { lgG1/k, } \\
\text { monoclonal } \\
\text { antibody }\end{array}$ & $\begin{array}{l}\text { IL-5 Receptor } \\
\text { alpha subunit } \\
\text { (IL-5R } \alpha)\end{array}$ & $\begin{array}{l}-\downarrow \text { eosinophils and basophils } \\
\text { via antibody dependent cell } \\
\text { mediated cytotoxicity (ADCC) }\end{array}$ & $\begin{array}{l}\text { - Reduction in exacerbation frequency } \\
\text { No significant effect on FEV1 } \\
\text { - Mixed data on quality of life and asthma } \\
\text { symptom scores (79) }\end{array}$ & $\begin{array}{l}\text { Decrease in airway smooth muscle mass } \\
\text { (predicted using computational modeling } \\
\text { approach) (80) }\end{array}$ & NA \\
\hline & Dupilumab & $\begin{array}{l}\text { human IgG4 } \\
\text { monoclonal } \\
\text { antibody }\end{array}$ & $\begin{array}{l}\text { IL-4 Receptor } \\
\text { alpha subunit } \\
\text { (IL-4R } \alpha)\end{array}$ & $\begin{array}{l}\text { - Blockage of IL-4/L-4R } \alpha \\
\text { binding } \\
\text { Blockage of IL-13/ } \\
\text { IL-4Ra binding }\end{array}$ & $\begin{array}{l}\text { - Reduced rate of severe asthma } \\
\text { exacerbations and improved lung function } \\
\text { (FEV1), asthma control and quality of life } \\
(81,82)\end{array}$ & $\begin{array}{l}\text { Studies on in vitro or in vivo effects of } \\
\text { dupilumab on airway remodeling are } \\
\text { currently non-available }\end{array}$ & $\begin{array}{l}\text { - Eczema } \\
\text { - Moderate-to-severe atopic } \\
\text { dermatitis in adolescents } \\
\text { - Chronic rhinosinusitis with } \\
\text { nasal polyps }\end{array}$ \\
\hline & Resliuzmab & $\begin{array}{l}\text { humanized lgG4/K } \\
\text { mAb }\end{array}$ & IL-5 & $\begin{array}{l}\text { - Blockage of IL-5/L-5R } \\
\text { binding } \\
0 \downarrow \text { circulating eosinophils } \\
\circ \downarrow \text { sputum eosinophils }\end{array}$ & $\begin{array}{l}\text { - Reduced exacerbations, improved FEV1, } \\
\text { forced vital capacity, the 7-item Asthma } \\
\text { Control Questionnaire (83) }\end{array}$ & $\begin{array}{l}\text { Studies on in vitro or in vivo effects of } \\
\text { reslizumab on airway remodeling are } \\
\text { currently non-available }\end{array}$ & NA \\
\hline \multirow[t]{6}{*}{$\begin{array}{l}\text { Drugs investigated } \\
\text { (currently or previously) } \\
\text { in severe asthma } \\
\text { treatment }\end{array}$} & Secukinumab & $\begin{array}{l}\text { human } \operatorname{lgG} 1 \kappa \\
\text { monoclonal } \\
\text { antibody }\end{array}$ & IL-17A & $\begin{array}{l}\text { B Blockage of IL17A -, -17F -, } \\
-17 \mathrm{~A} / \mathrm{F} \text { heterodimer -, and } \\
\text {-17E-(IL-25)/LL-17RA } \\
\text { binding }\end{array}$ & NA & $\begin{array}{l}\text { Studies on in vitro or in vivo effects of } \\
\text { secukinumab on airway remodeling are } \\
\text { currently non-available }\end{array}$ & $\begin{array}{l}\text { - Plaque psoriasis } \\
\text { - Psoriatic arthritis } \\
\text { - Ankylosing spondylitis } \\
\text { - Discontinued in asthma }\end{array}$ \\
\hline & Brodalumab & $\begin{array}{l}\text { human, lgG2 } \\
\text { monoclonal } \\
\text { antibody }\end{array}$ & $\begin{array}{l}\text { IL-17 receptor A } \\
\text { (L-17RA) }\end{array}$ & $\begin{array}{l}\text { Blockage of IL17A -, -17F -, } \\
\text {-17A/F heterodimer -, and } \\
\text {-17E-(IL-25) /L-17RA } \\
\text { binding }\end{array}$ & $\begin{array}{l}\text { - No significant improvement in lung function } \\
\text { (FEV1) and asthma control in subjects with } \\
\text { inadequately controlled moderate to severe } \\
\text { asthma (84) }\end{array}$ & $\begin{array}{l}\text { Studies on in vitro or in vivo effects of } \\
\text { brodalumab on airway remodeling are } \\
\text { currently non-available }\end{array}$ & Plaque psoriasis \\
\hline & Tralokinumab & $\begin{array}{l}\text { Human IgG4 } \\
\text { monoclonal } \\
\text { antibody }\end{array}$ & IL-13 & $\begin{array}{l}\text { - Blockage of IL-13/L-13R } \alpha 1 \\
\text { - Blockage of } \\
\text { IL-13/L-13R } \alpha 2 \text { binding }\end{array}$ & $\begin{array}{l}\text { Inconsistent effects on annualized asthma } \\
\text { exacerbation rate (85) - development of } \\
\text { tralokinumab in severe asthma was } \\
\text { discontinued by the producer after this } \\
\text { study (86) }\end{array}$ & $\begin{array}{l}\text { - No significant effect on bronchial } \\
\text { eosinophilic count } \\
\text { - No significant reduction of airway } \\
\text { remodeling in bronchial biopsy } \\
\text { features-Airway smooth muscle }\end{array}$ & $\begin{array}{l}\text { - None available (possibly } \\
\text { in atopic dermatitis in the } \\
\text { future) (88) } \\
\text { - Discontinued in asthma }\end{array}$ \\
\hline & & & & & $\begin{array}{l}\text { - No significant improvement of lung function } \\
\text { (FEV1) (87) }\end{array}$ & $\begin{array}{l}\text { area, RBM thickness, collagen type IV, } \\
\text { periostin, TGF } \beta \text { and other (87) }\end{array}$ & \\
\hline & Secukinumab & $\begin{array}{l}\text { Humanized lgG4 } \\
\text { monoclonal } \\
\text { antibody }\end{array}$ & IL-13 & $\begin{array}{l}\text { Blockage of IL-13/L-13R } \alpha 1 \\
\text {. Blockage of } \\
\text { IL-13/L-13R } \alpha 2 \text { binding }\end{array}$ & $\begin{array}{l}\text { - Decrease in asthma exacerbations } \\
\text { incidence } \\
\text { - Improved lung function (FEV1\%) (89) }\end{array}$ & $\begin{array}{l}\text { - Greater clinical effects (decrease in } \\
\text { exacerbation rate and improvement in } \\
\text { lung function) in patients with high serum } \\
\text { periostin levels - a protein contributing to } \\
\text { airway remodeling (90) }\end{array}$ & $\begin{array}{l}\text { - None available (possibly } \\
\text { in atopic dermatitis in } \\
\text { the future)(91) } \\
\text { - Discontinued in asthma }\end{array}$ \\
\hline & $\begin{array}{l}\text { Tezepelumab } \\
\text { (AMG 157) }\end{array}$ & $\begin{array}{l}\text { human, IgG2 } \\
\text { monoclonal } \\
\text { antibody }\end{array}$ & TSLP & $\begin{array}{l}\text { - Blockage of } \\
\text { TSLP/TSLP-receptor binding }\end{array}$ & $\begin{array}{l}\text { - Inhibition of late allergen-induced asthmatic } \\
\text { response (FEV1) (92) } \\
\text { - Reduction of annualized asthma } \\
\text { exacerbation rate (93) }\end{array}$ & $\begin{array}{l}\text { - Studies on in vitro or in vivo effects of } \\
\text { tezepelumab on airway remodeling are } \\
\text { currently non-available }\end{array}$ & NA \\
\hline
\end{tabular}


omalizumab treatment significantly reduced the airway wall thickness measures: airway wall area corrected for body surface area (WA/BSA) -13.7 to $12.1 \mathrm{~mm}^{2} / \mathrm{m}^{2}$, percentage wall area (WA\%) -71.1 to $64.7 \%$ and wall thickness $(\mathrm{T}) / \sqrt{ } \mathrm{BSA}-1.21$ to $0.92 \mathrm{~mm} / \mathrm{m}$. Luminal area (Ai/BSA) at the right apical segmental bronchus significantly increased $\left(4.8\right.$ to $\left.6.4 \mathrm{~mm}^{2} / \mathrm{m}^{2}\right)$ and the percentage of sputum eosinophils significantly decreased. These effects were not observed in the conventional therapy group (74).

Tajiri also studied effects of omalizumab in regard to AR in a 48-week follow-up of omalizumab in 26 patients (CT measurements were analyzed in 14 patients). A significant reductions of WA\% was observed (57.1 vs. baseline 62.0) and a small, but significant, increase in Ai/BSA (12.1 vs. baseline 12.0) (75).

However, Przybyszowski et al. reached slightly different results to the above. The authors analyzed changes of HRCT airway dimensions in 12 patients before and after at least 4 months of omalizumab treatment. They observed a decrease in airway wall area and WA/BSA, but no changes in WA\% nor in luminal area to total bronchial area ratio (94).

\section{Mepolizumab}

Flood-Page published in 2003 a study on the effects of mepolizumab on AR markers in bronchial biopsies of 24 atopic asthmatics from a randomized, double-bind, placebocontrolled study, which were obtained before and after three mepolizumab infusions. Compared to placebo, treatment with mepolizumab significantly reduced the expression of three extracellular matrix proteins: tenascin, lumican and procollagen III in the reticular basement membrane. Moreover, mepolizumab significantly reduced the number and percentage of airway eosinophils expressing TGF $\beta_{1}$ mRNA and decreased TGF $\beta_{1}$ in BAL fluid (77).

Only one clinical study (12-month mepolizumab vs. placebo trial, 61 subjects) analyzed the effect of mepolizumab on AR. The mean change in CT measured wall area and total area corrected for body surface area was significantly greater in treatment group than in placebo group. In fact, in mepolizumab group the values decreased whereas in placebo group an increase of these parameters was observed (78).

\section{Benralizumab}

A very interesting approach in assessing effects of benralizumab on AR was taken by Chachi et al. (80). The researchers used bronchial biopsies of 15 patients on benralizumab and 10 patients receiving placebo, which were collected from subjects with eosinophilic asthma during a previous phase I multicenter, randomized, double-blind, placebo-controlled trial (95). The eosinophil count in airway lamina propria was assessed in pre- and post-treatment biopsies. It decreased significantly in benralizumab group by $66.4 \%$ and by $88 \%$ relative to placebo. Knowing the mechanism of action of benralizumab, and with the observed mean change in eosinophil count, the authors used a computational model to predict effects of this drug on AR. They concluded that in benralizumab group the drugs proapoptosis efficiency was $47 \%$, corresponding to a consequent $29 \%$ relative reduction of ASM mass. Additionally, in the benralizumab group, a non-significant reduction in the number of tissue myofibroblasts was observed. The authors suggest that as ASM cells do not express IL-5R, the effects of benralizumab on ASM mass are an indirect effect of reduced eosinophilic inflammation. They proposed an assumption that depletion of local eosinophils results in decrease of airway TGF $\beta$-a major growth factor contributing to AR, which is majorly expressed in lungs by the eosinophils.

\section{Other Antibodies (Dupilumab, Reslizumab, Secukinumab, Brodalumab, Tralokinumab, Lebrikizumab, Tezepelumab)}

To authors knowledge, no study covered any aspect of AR alleviation (either in vitro, in vivo in animal models or in vivo in humans) in therapy with FDA-approved dupilumab and reslizumab. The issue was also not addressed regarding secukinumab, brodalumab, and tezepelumab-which were clinically studied in asthma, but are now discontinued in this indication.

Fragmentary data can be found regarding tralokinumab and lebrikizumab. In a phase 2 trial of tralokinumab in asthma, features of AR in bronchial biopsies (ASM area, RBM thickness, collagen type IV, periostin, TGF $\beta$ and other) were not reduced, neither was the bronchial eosinophilic infiltration (87). Lebrikizumab in turn showed greater clinical effects (decreased exacerbation rate and improved lung function) in asthmatic patients with high serum periostin levels (protein contributing to AR) in a phase 2 trial (90). However, the two drugs' development in asthma is also discontinued.

\section{SUMMARY}

According to the American Thoracic Society (ATS) 2017 expertise-and other researchers' opinions $(16,96)$-it should be further investigated whether, and if so, to what extent, biological therapy of asthma significantly affects $A R$ and what are the clinical consequences of such an effect. Moreover, research on AR was indicated by ATS as crucial in the development of knowledge about asthma and its treatment. The need to monitor AR in future clinical studies is pointed out as an important aspect of response to modern biological treatment of severe asthma. These recommendations also highlight the need to study the impact of currently available biological preparations on AR and to look for new drugs that alleviate it (97).

The development of biological therapies has opened a new chapter in treatment of severe asthma. Since the introduction of the first monoclonal antibody in this disease-the anti-IgE drug omalizumab in 2004-a new range of biology-oriented therapy emerged. With the arrival of the subsequent antibodies targeting other molecules involved in asthma pathophysiology, it became possible to treat the most severely ill patients using phenotype-oriented drugs. However, as only since recent years new drugs in this field arrive, little is known about their effect on the AR-a key clinical feature of severe asthma and its longlasting consequences. The data available to date confirms with a high degree of probability only the beneficial role of omalizumab 
in reversing AR. Some promising studies cover this topic in regard to mepolizumab and benralizumab. Yet, future research of available and upcoming biological therapies in severe asthma shall address this clinical issue as an important feature of longterm severe asthma management.

\section{REFERENCES}

1. GINA. Global Strategy for Asthma Management and Prevention Updated 2020. (2020). Available online at: www.ginasthma.org (accessed April 7, 2020).

2. Wenzel SE. Asthma phenotypes: the evolution from clinical to molecular approaches. Nat Med. (2012) 18:716-25. doi: 10.1038/nm.2678

3. Liebhart J, Dobek R, Małolepszy J, Wojtyniak B, Pisiewicz K, Płusa T, et al. The prevalence of allergic diseases in Poland-the results of the PMSEAD study in relation to gender differences. Adv Clin Exp Med. (2014) 23:75762. doi: $10.17219 /$ acem $/ 37238$

4. Samolinski B, Raciborski F, Lipiec A, Tomaszewska A, Krzych-Fałta E, SamelKowalik P, et al. Epidemiologia Chorób Alergicznych w Polsce (ECAP) Epidemiology of allergic diseases in Poland. Otolaryngol Pol. (2014) 1:108. doi: 10.1016/j.alergo.2014.03.008

5. Schatz M, Rosenwasser L. The allergic asthma phenotype. J Allergy Clin Immunol Pract. (2014) 2:645-8. doi: 10.1016/j.jaip.2014.09.004

6. Hirano T, Matsunaga K. Late-onset asthma: current perspectives. J Asthma Allergy. (2018) 11:19-27. doi: 10.2147/JAA.S125948

7. Akinbami LJ, Moorman JE, Bailey C, Zahran HS, King M, Johnson CA, et al. Trends in asthma prevalence, health care use, and mortality in the United States, 2001-2010. NCHS Data Brief. (2012) 1-8.

8. Lundbäck B, Backman $H$, Lötvall J, Rönmark E. Is asthma prevalence still increasing? Expert Rev Respir Med. (2016) 10:39-51. doi: 10.1586/17476348.2016.1114417

9. Burbank AJ, Sood AK, Kesic MJ, Peden DB, Hernandez ML. Environmental determinants of allergy and asthma in early life. J Allergy Clin Immunol. (2017) 140:1-12. doi: 10.1016/j.jaci.2017.05.010

10. Strannegard O, Strannegard I-L. The causes of the increasing prevalence of allergy: is atopy a microbial deprivation disorder? Allergy. (2001) 56:91102. doi: 10.1034/j.1398-9995.2001.056002091.x

11. Carr TF, Zeki AA, Kraft M. Eosinophilic and noneosinophilic asthma. Am J Respir Crit Care Med. (2018) 197:22-37. doi: 10.1164/rccm.201611-2 232PP

12. De Groot JC, Brinke A, Ten Bel EHD. Management of the patient with eosinophilic asthma: a new era begins. ERJ Open Res. (2015) 1:000242015. doi: 10.1183/23120541.00024-2015

13. Fahy JV. Type 2 inflammation in asthma-present in most, absent in many. Nat Rev Immunol. (2015) 15:57-65. doi: 10.1038/nri3786

14. Papi A, Brightling C, Pedersen SE, Reddel HK. Asthma. Lancet. (2018) 391:783-800. doi: 10.1016/S0140-6736(17)33311-1

15. Chau-Etchepare F, Hoerger JL, Kuhn BT, Zeki AA, Haczku A, Louie S, et al. Viruses and non-allergen environmental triggers in asthma. J Investig Med. (2019) 67:1029-41. doi: 10.1136/jim-2019-001000

16. Boulet LP. Airway remodeling in asthma: update on mechanisms and therapeutic approaches. Curr Opin Pulm Med. (2018) 24:56-62. doi: 10.1097/MCP.0000000000000441

17. King GG, Noble PB. Airway remodelling in asthma: it's not going away. Respirology. (2016) 21:203-4. doi: 10.1111/resp.12727

18. Holgate ST. Pathogenesis of asthma. Clin Exp Allergy. (2008) 38:87297. doi: 10.1111/j.1365-2222.2008.02971.x

19. Bergeron C, Boulet L-P. Structural changes in airway diseases. Chest. (2006) 129:1068-87. doi: 10.1378/chest.129.4.1068

20. Pelaia G, Vatrella A, Maselli R. Airway Remodelling in Asthma. In: Asthma: Targeted Biological Therapies. Cham: Springer International Publishing (2017). p. 17-25. doi: 10.1007/978-3-319-46007-9_3

21. Salter B, Pray C, Radford K, Martin JG, Nair P. Regulation of human airway smooth muscle cell migration and relevance to asthma. Respir Res. (2017) 18:156. doi: 10.1186/s12931-017-0640-8

\section{AUTHOR CONTRIBUTIONS}

GK and MP created the concept of the paper. GK conducted the literature research and wrote the manuscript. PK and MP revised the paper.

22. Doherty T, Broide D. Cytokines and growth factors in airway remodeling in asthma. Curr Opin Immunol. (2007) 19:676-80. doi: 10.1016/j.coi.2007.07.017

23. Halwani R, Al-Muhsen S, Al-Jahdali H, Hamid Q. Role of transforming growth factor- $\beta$ in airway remodeling in asthma. Am J Respir Cell Mol Biol. (2011) 44:127-33. doi: 10.1165/rcmb.2010-0027TR

24. Kardas G, Daszynska-Kardas A, Marynowski M, Brzakalska O, Kuna P, Panek M. Role of Platelet-Derived Growth Factor (PDGF) in asthma as an immunoregulatory factor mediating airway remodeling and possible pharmacological target. Front Pharmacol. (2020) 11:47. doi: 10.3389/fphar.2020.00047

25. Samitas K, Delimpoura V, Zervas E, Gaga M. Anti-IgE treatment, airway inflammation and remodelling in severe allergic asthma: current knowledge and future perspectives. Eur Respir Rev. (2015) 24:594601. doi: 10.1183/16000617.00001715

26. Redhu NS, Shan L, Al-Subait D, Ashdown HL, Movassagh H, Lamkhioued $\mathrm{B}$, et al. IgE induces proliferation in human airway smooth muscle cells: role of MAPK and STAT3 pathways. Allergy, Asthma Clin Immunol. (2013) 9:41. doi: 10.1186/1710-1492-9-41

27. Batra V, Musani AI, Hastie AT, Khurana S, Carpenter KA, Zangrilli JG, et al. Bronchoalveolar lavage fluid concentrations of transforming growth factor (TGF)- $\beta 1$, TGF- $\beta 2$, interleukin (IL)- 4 and IL-13 after segmental allergen challenge and their effects on $\alpha$-smooth muscle actin and collagen III synthesis by primary human lung fibroblasts. Clin Exp Allergy. (2004) 34:43744. doi: 10.1111/j.1365-2222.2004.01885.x

28. Richter A, Puddicombe SM, Lordan JL, Bucchieri F, Wilson SJ, Djukanović $\mathrm{R}$, et al. The contribution of interleukin (IL)-4 and IL-13 to the epithelialmesenchymal trophic unit in asthma. Am J Respir Cell Mol Biol. (2001) 25:385-91. doi: 10.1165/ajrcmb.25.3.4437

29. Cho JY, Miller M, Baek KJ, Han JW, Nayar J, Lee SY, et al. Inhibition of airway remodeling in IL-5-deficient mice. J Clin Invest. (2004) 113:55160. doi: 10.1172/JCI19133

30. Tanaka H, Komai M, Nagao K, Ishizaki M, Kajiwara D, Takatsu K, et al. Role of interleukin-5 and eosinophils in allergen-induced airway remodeling in mice. Am J Respir Cell Mol Biol. (2004) 31:62-8. doi: 10.1165/rcmb.2003-0305OC

31. Malavia NK, Mih JD, Raub CB, Dinh BT, George SC. IL-13 induces a bronchial epithelial phenotype that is profibrotic. Respir Res. (2008) 9:27. doi: 10.1186/1465-9921-9-27

32. Atherton HC, Jones G, Danahay H. IL-13-induced changes in the goblet cell density of human bronchial epithelial cell cultures: MAP kinase and phosphatidylinositol 3-kinase regulation. Am J Physiol Lung Cell Mol Physiol. (2003) 285:L730-9. doi: 10.1152/ajplung.00089.2003

33. Chang Y, Al-Alwan L, Risse PA, Roussel L, Rousseau S, Halayko AJ, et al. TH17 cytokines induce human airway smooth muscle cell migration. J Allergy Clin Immunol. (2011) 127:1046-53.e12. doi: 10.1164/ajrccm-conference.2010.181.1_MeetingAbstracts.A2128

34. Camargo LD, Righetti RF, Aristóteles LR, dos Santos TM, de Souza FC, Fukuzaki S, et al. Effects of Anti-IL-17 on inflammation, remodeling, and oxidative stress in an experimental model of asthma exacerbated by LPS. Front. Immunol. (2018) 8:1835. doi: 10.3389/fimmu.2017.01835

35. Evasovic JM, Singer CA. Regulation of IL-17A and implications for TGF- $\beta 1$ comodulation of airway smooth muscle remodeling in severe asthma. Am J Physiol Lung Cell Mol Physiol. (2019) 316:L843-L868. doi: 10.1152/ajplung.00416.2018

36. Hayashi H, Kawakita A, Okazaki S, Yasutomi M, Murai H, Ohshima Y. IL$17 \mathrm{~A} / \mathrm{F}$ modulates fibrocyte functions in cooperation with CD40-mediated signaling. Inflammation. (2013) 36:830-8. doi: 10.1007/s10753-013-9609-Z

37. Chen ZG, Zhang TT, Li HT, Chen FH, Zou XL, Ji JZ, et al. Neutralization of TSLP inhibits airway remodeling in a murine model of allergic asthma 
induced by chronic exposure to house dust mite. PLoS ONE. (2013) 8:51268. doi: 10.1371/journal.pone.0051268

38. Cao L, Liu F, Liu Y, Liu T, Wu J, Zhao J, et al. TSLP promotes asthmatic airway remodeling via p38-STAT3 signaling pathway in human lung fibroblast. Exp Lung Res. (2018) 44:288-301. doi: 10.1080/01902148.2018.15 36175

39. Kalluri R, Weinberg RA. The basics of epithelial-mesenchymal transition. $J$ Clin Invest. (2009) 119:1420-8. doi: 10.1172/JCI39104

40. Hackett T-L. Epithelial-mesenchymal transition in the pathophysiology of airway remodelling in asthma. Curr Opin Allergy Clin Immunol. (2012) 12:53-9. doi: 10.1097/ACI.0b013e32834ec6eb

41. Pain M, Bermudez O, Lacoste P, Royer PJ, Botturi K, Tissot A, et al. Tissue remodelling in chronic bronchial diseases: from the epithelial to mesenchymal phenotype. Eur Respir Rev. (2014) 23:118-30. doi: 10.1183/09059180.00004413

42. Hackett TL, Warner SM, Stefanowicz D, Shaheen F, Pechkovsky DV, Murray LA, et al. Induction of epithelial-mesenchymal transition in primary airway epithelial cells from patients with asthma by transforming growth factor- $\beta 1$. Am J Respir Crit Care Med. (2009) 180:122-33. doi: 10.1164/rccm.200811-1730OC

43. Ji X, Li J, Xu L, Wang W, Luo M, Luo S, et al. IL4 and IL-17A provide a Th2/Th17-polarized inflammatory milieu in favor of TGF- $\beta 1$ to induce bronchial epithelial-mesenchymal transition (EMT). Int J Clin Exp Pathol. (2013) 6:1481-92.

44. Haddad A, Gaudet M, Plesa M, Allakhverdi Z, Mogas AK, Audusseau $S$, et al. Neutrophils from severe asthmatic patients induce epithelial to mesenchymal transition in healthy bronchial epithelial cells. Respir Res. (2019) 20:234. doi: 10.1186/s12931-019-1186-8

45. Bartis D, Mise N, Mahida RY, Eickelberg O, Thickett DR. Epithelialmesenchymal transition in lung development and disease: does it exist and is it important? Thorax. (2014) 69:760-5. doi: 10.1136/thoraxjnl-2013-2 04608

46. Sohal SS, Ward C, Walters EH. Importance of epithelial mesenchymal transition (EMT) in COPD and asthma. Thorax. (2014) 69:768. doi: 10.1136/thoraxjnl-2014-205582

47. Halwani R, Al-Muhsen S, Hamid Q. Airway remodeling in asthma. Curr Opin Pharmacol. (2010) 10:236-45. doi: 10.1016/j.coph.2010.06.004

48. James AL, Wenzel S. Clinical relevance of airway remodelling in airway diseases. Eur Respir J. (2007) 30:134-55. doi: 10.1183/09031936.001 46905

49. Pascual RM, Peters SP. Airway remodeling contributes to the progressive loss of lung function in asthma: an overview. J Allergy Clin Immunol. (2005) 116:477-86. doi: 10.1016/j.jaci.2005.07.011

50. Backman H, Jansson S, Stridsman C, Eriksson B, Hedman L, Eklund B, et al. Severe asthma-a population study perspective. Clin Exp Allergy. (2019) 49:819-28. doi: 10.1111/cea.13378

51. Hekking PPW, Wener RR, Amelink M, Zwinderman AH, Bouvy ML, Bel EH. The prevalence of severe refractory asthma. J Allergy Clin Immunol. (2015) 135:896-902. doi: 10.1016/j.jaci.2014.08.042

52. Larsson K, Ställberg B, Lisspers K, Telg G, Johansson G, Thuresson M, et al. Prevalence and management of severe asthma in primary care: an observational cohort study in Sweden (PACEHR). Respir Res. (2018) 19:12. doi: 10.1186/s12931-018-0719-x

53. Israel E, Reddel HK. Severe and difficult-to-treat asthma in adults. N Engl J Med. (2017) 377:965-76. doi: 10.1056/NEJMra16 08969

54. Nunes C, Pereira AM, Morais-Almeida M. Asthma costs and social impact. Asthma Res Pract. (2017) 3:1-11. doi: 10.1186/s40733-016-0029-3

55. Sadatsafavi M, Lynd L, Marra C, Carleton B, Tan WC, Sullivan S, FitzGerald JM. Direct health care costs associated with asthma in British Columbia. Can Respir J. (2010) 17:74-80. doi: 10.1155/2010/361071

56. Koski RR, Grzegorczyk KM. Comparison of monoclonal antibodies for treatment of uncontrolled eosinophilic asthma. J Pharm Pract. (2019). doi: 10.1177/0897190019840597. [Epub ahead of print].

57. Schulman ES. Development of a monoclonal anti-immunoglobulin E antibody (Omalizumab) for the treatment of allergic respiratory disorders. Am J Respir Crit Care Med. (2001) 164:S6-S11. doi: 10.1164/ajrccm.164.supplement_1.2103025
58. Kawakami T, Blank U. From IgE to omalizumab. J Immunol. (2016) 197:418792. doi: 10.4049/jimmunol.1601476

59. Alhossan A, Lee CS, MacDonald K, Abraham I. "Real-life" effectiveness studies of omalizumab in adult patients with severe allergic asthma: meta-analysis. J Allergy Clin Immunol Pract. (2017) 5:1362-70.e2. doi: 10.1016/j.jaip.2017.02.002

60. Esquivel A, Busse WW, Calatroni A, Togias AG, Grindle KG, Bochkov YA, et al. Effects of omalizumab on rhinovirus infections, illnesses, and exacerbations of asthma. Am J Respir Crit Care Med. (2017) 196:98592. doi: 10.1164/rccm.201701-01200C

61. Pelaia C, Calabrese C, Terracciano R, de Blasio F, Vatrella A, Pelaia G. Omalizumab, the first available antibody for biological treatment of severe asthma: more than a decade of real-life effectiveness. Ther Adv Respir Dis. (2018) 12:1-16. doi: 10.1177/1753466618810192

62. Adachi M, Kozawa M, Yoshisue H, Lee Milligan K, Nagasaki M, Sasajima T, et al. Real-world safety and efficacy of omalizumab in patients with severe allergic asthma: a long-term post-marketing study in Japan. Respir Med. (2018) 141:56-63. doi: 10.1016/j.rmed.2018.06.021

63. Long A, Rahmaoui A, Rothman KJ, Guinan E, Eisner M, Bradley MS, et al. Incidence of malignancy in patients with moderate-to-severe asthma treated with or without omalizumab. J Allergy Clin Immunol. (2014) 134. doi: 10.1016/j.jaci.2014.02.007

64. Namazy J, Cabana MD, Scheuerle AE, Thorp JM, Chen H, Carrigan $\mathrm{G}$, et al. The Xolair Pregnancy Registry (EXPECT): the safety of omalizumab use during pregnancy. J Allergy Clin Immunol. (2015) 135:40712. doi: $10.1016 /$ j.jaci.2014.08.025

65. Busse WW, Morgan WJ, Gergen PJ, Mitchell HE, Gern JE, Liu AH, et al. Randomized trial of omalizumab (Anti-IgE) for asthma in inner-city children. N Engl J Med. (2011) 364:1005-15. doi: 10.1056/NEJMoa1009705

66. Fala L. Nucala (Mepolizumab): First IL-5 antagonist monoclonal antibody FDA approved for maintenance treatment of patients with severe asthma. Am Heal Drug Benefits. (2016) 9:106-10.

67. Bel EH, Wenzel SE, Thompson PJ, Prazma CM, Keene ON, Yancey SW, et al. Oral glucocorticoid-sparing effect of mepolizumab in eosinophilic asthma. $N$ Engl J Med. (2014) 371:1189-97. doi: 10.1056/NEJMoa1403291

68. Ortega HG, Liu MC, Pavord ID, Brusselle GG, FitzGerald JM, Chetta A, et al. Mepolizumab treatment in patients with severe eosinophilic asthma. $N$ Engl J Med. (2014) 371:1198-207. doi: 10.1056/NEJMoa1403290

69. Cockle SM, Stynes G, Gunsoy NB, Parks D, Alfonso-Cristancho R, Wex J, et al. Comparative effectiveness of mepolizumab and omalizumab in severe asthma: an indirect treatment comparison. Respir Med. (2017) 123:1408. doi: 10.1016/j.rmed.2016.12.009

70. McCracken JL, Tripple JW, Calhoun WJ. Biologic therapy in the management of asthma. Curr Opin Allergy Clin Immunol. (2016) 16:37582. doi: $10.1097 / \mathrm{ACI} .0000000000000284$

71. Patel SS, Casale TB, Cardet JC. Biological therapies for eosinophilic asthma. Expert Opin Biol Ther. (2018) 18:74754. doi: 10.1080/14712598.2018.1492540

72. Huang YC, Leyko B, Frieri M. Effects of omalizumab and budesonide on markers of inflammation in human bronchial epithelial cells. Ann Allergy, Asthma Immunol. (2005) 95:443-51. doi: 10.1016/S1081-1206(10)61170-2

73. Roth M, Zhao F, Zhong J, Lardinois D, Tamm M. Serum IgE induced airway smooth muscle cell remodeling is independent of allergens and is prevented by omalizumab. PLOS ONE. (2015) 10:e0136549. doi: 10.1371/journal.pone.0136549

74. Hoshino M, Ohtawa J. Effects of adding omalizumab, an antiimmunoglobulin $\mathrm{E}$ antibody, on airway wall thickening in asthma. Respiration. (2012) 83:520-8. doi: 10.1159/000334701

75. Tajiri T, Niimi A, Matsumoto $H$, Ito I, Oguma T, Otsuka $K$, et al. Comprehensive efficacy of omalizumab for severe refractory asthma: a timeseries observational study. Ann Allergy, Asthma Immunol. (2014) 113:470475.e2. doi: 10.1016/j.anai.2014.06.004

76. Liu Y, Zhang S, Li DW, Jiang SJ. Efficacy of anti-interleukin-5 therapy with mepolizumab in patients with asthma: a metaanalysis of randomized placebo-controlled trials. PLOS ONE. (2013) 8:e59872. doi: 10.1371/annotation/8da4be4b-2de1-4c51-9c40-0f49dc212579

77. Flood-Page P, Menzies-Gow A, Phipps S, Ying S, Wangoo A, Ludwig MS, et al. Anti-IL-5 treatment reduces deposition of ECM proteins in the bronchial 
subepithelial basement membrane of mild atopic asthmatics. J Clin Invest. (2003) 112:1029-36. doi: 10.1172/JCI17974

78. Haldar P, Brightling CE, Hargadon B, Gupta S, Monteiro W, Sousa A, et al. Mepolizumab and exacerbations of refractory eosinophilic asthma. $N$ Engl J Med. (2009) 360:973-84. doi: 10.1056/NEJMoa0808991

79. Saco TV, Pepper AN, Lockey RF. Benralizumab for the treatment of asthma. Expert Rev Clin Immunol. (2017) 13:40513. doi: $10.1080 / 1744666 X .2017 .1316194$

80. Chachi L, Diver S, Kaul H, Rebelatto MC, Boutrin A, Nisa P, et al. Computational modelling prediction and clinical validation of impact of benralizumab on airway smooth muscle mass in asthma. Eur Respir J. (2019) 54:1900930. doi: 10.1183/13993003.00930-2019

81. Deeks ED. Dupilumab: a review in moderate to severe asthma. Drugs. (2019) 79:1885-95. doi: 10.1007/s40265-019-01221-x

82. Santini G, Mores N, Malerba M, Mondino C, Anzivino R, Macis G, et al. Dupilumab for the treatment of asthma. Expert Opin Investig Drugs. (2017) 26:357-66. doi: 10.1080/13543784.2017.1282458

83. Walsh GM. Reslizumab in the treatment of severe eosinophilic asthma: an update. Immunotherapy. (2018) 10:695-8. doi: 10.2217/imt-2017-0176

84. Busse WW, Holgate S, Kerwin E, Chon Y, Feng J, Lin J, et al. Study of brodalumab, a human anti - IL-17 receptor monoclonal antibody, in moderate to severe asthma. Am J Respir Crit Care Med. (2013) 188:1294302. doi: $10.1164 / \mathrm{rccm} .201212-2318 \mathrm{OC}$

85. Panettieri RA, Sjöbring U, Péterffy AM, Wessman P, Bowen K, Piper E, et al. Tralokinumab for severe, uncontrolled asthma (STRATOS 1 and STRATOS 2): two randomised, double-blind, placebo-controlled, phase 3 clinical trials. Lancet Respir Med. (2018) 6:511-25. doi: 10.1016/S2213-2600(18)30184-X

86. Chung KF. Tralokinumab unsuccessful for management of severe, uncontrolled asthma. Lancet Respir Med. (2018) 6:4801. doi: 10.1016/S2213-2600(18)30194-2

87. Russell RJ, Chachi L, FitzGerald JM, Backer V, Olivenstein R, Titlestad IL, et al. Effect of tralokinumab, an interleukin-13 neutralising monoclonal antibody, on eosinophilic airway inflammation in uncontrolled moderateto-severe asthma (MESOS): a multicentre, double-blind, randomised, placebo-controlled phase 2 trial. Lancet Respir Med. (2018) 6:499510. doi: 10.1016/S2213-2600(18)30201-7

88. Wollenberg A, Howell MD, Guttman-Yassky E, Silverberg JI, Kell C, Ranade $\mathrm{K}$, et al. Treatment of atopic dermatitis with tralokinumab, an anti-IL-13 mAb. J Allergy Clin Immunol. (2019) 143:135-41. doi: 10.1016/j.jaci.2018.05.029

89. Liu Y, Zhang S, Chen R, Wei J, Guan G, Zhou M, et al. Meta-analysis of randomized controlled trials for the efficacy and safety of anti-interleukin13 therapy with lebrikizumab in patients with uncontrolled asthma. Allergy Asthma Proc. (2018) 39:332-7. doi: 10.2500/aap.2018.39.4149
90. Corren J, Lemanske RF, Hanania NA, Korenblat PE, Parsey MV, Arron JR, et al. Lebrikizumab treatment in adults with asthma. $N \quad$ Engl J Med. (2011) 365:1088-98. doi: 10.1056/NEJMoal1 06469

91. Loh TY, Hsiao JL, Shi VY. Therapeutic potential of lebrikizumab in the treatment of atopic Dermatitis. J Asthma Allergy. (2020) 13:10914. doi: 10.2147/JAA.S211032

92. Gauvreau GM, O’Byrne PM, Boulet L-P, Wang Y, Cockcroft D, Bigler J, et al. Effects of an Anti-TSLP antibody on allergen-induced asthmatic responses. N Engl J Med. (2014) 370:2102-10. doi: 10.1056/NEJMoa14 02895

93. Corren J, Parnes JR, Wang L, Mo M, Roseti SL, Griffiths JM, et al. Tezepelumab in adults with uncontrolled asthma. N Engl J Med. (2017) 377:936-46. doi: 10.1056/NEJMoa1704064

94. Przybyszowski M, Paciorek K, Zastrzezynska W, Gawlewicz-Mroczka A, Trojan-Królikowska A, Orłowska A, et al. Influence of omalizumab therapy on airway remodeling assessed with high-resolution computed tomography (HRCT) in severe allergic asthma patients. Adv Respir Med. (2018) 86:282-90. doi: 10.1183/13993003.congress-2018.P A5047

95. Laviolette M, Gossage DL, Gauvreau G, Leigh R, Olivenstein R, Katial R, et al. Effects of benralizumab on airway eosinophils in asthmatic patients with sputum eosinophilia. $J$ Allergy Clin Immunol. (2013) 132:1086-96.e5. doi: 10.1016/j.jaci.2013. 05.020

96. Robinson DS. Mepolizumab treatment for asthma. Expert Opin Biol Ther. (2013) 13:295-302. doi: 10.1517/14712598.2012.7 25717

97. Prakash YS, Halayko AJ, Gosens R, Panettieri Jr RA, Camoretti-Mercado B, Penn RB. An official American Thoracic Society research statement: current challenges facing research and therapeutic advances in airway remodeling. Am J Respir Crit Care Med. (2017) 195:e4-19. doi: 10.1164/rccm.201611-2 $248 \mathrm{ST}$

Conflict of Interest: The authors declare that the research was conducted in the absence of any commercial or financial relationships that could be construed as a potential conflict of interest.

Copyright $\odot 2020$ Kardas, Kuna and Panek. This is an open-access article distributed under the terms of the Creative Commons Attribution License (CC BY). The use, distribution or reproduction in other forums is permitted, provided the original author(s) and the copyright owner(s) are credited and that the original publication in this journal is cited, in accordance with accepted academic practice. No use, distribution or reproduction is permitted which does not comply with these terms. 